GLOBAL JOURNAL OF GEOLOGICAL SCIENCES VOL. 13, 2015: 9-14

COPYRIGHT@ BACHUDO SCIENCE CO. LTD PRINTED IN NIGERIA ISSN 1118-0579

www.globaljournalseries.com, Email: info@globaljournalseries.com

\title{
MORPHOMETRIC FEATURES OF A LOW-ELEVATION URBAN CATCHMENT AND THE IMPLICATIONS FOR FLOODING
}

PRECIOUS N. EDE

(Received 2 October 2014; Revision Accepted 15 November 2014)

\begin{abstract}
River basin morphometric is a geomorphological tool that applies to physical measurements about a river form, from which can be derived quantities that explain its characteristics, such as size, shape, stream network and discharge. This paper used basin morphometric to assess flood occurrence in Port Harcourt, Nigeria. Previous analysis of Port Harcourt region's drainage as it pertains to flooding described the area as lacking significant displacement in relief; therefore, rivers were characterized by sluggish flow velocity, ponded in many parts and tidal in others. The consequence of absence of gradient as described by these authors is an area prone to widespread flooding; however, the basis of their observations was their reliance on topographic maps whose contour intervals were $15.24 \mathrm{~m}$ in elevation. Extant topographic maps of the area were used in this study to render and extend contour lines to hitherto, flat surfaces at intervals of $3 \mathrm{~m}$. The result was a map with fairly crowded contour lines of the area described as Greater Port Harcourt city, which comprises the old city and all the on-going developments and proposed new city limits. The basin is a $3^{\text {rd }}$ order basin; there were 6 first order streams, 3 second order streams and 1 third order stream. Flooding in the northern part of the metropolis is caused by the ponding of depressions and human settlement practices like roads and widespread concrete fences. In the south, very low elevation ranging between $0-12 \mathrm{~m}$ and extensive tidal mudflats transformed into human habitation predispose it to flooding. This study proposes that ponded areas be carefully drained and low lying areas adequately planed and managed to check flooding in the city.
\end{abstract}

KEYWORDS: Basin Morphometric; Urban Flooding; Greater Port Harcourt; Ponded Depressions.

\section{INTRODUCTION}

River basin morphometric is a geomorphological tool that applies to physical measurements about a river form, from which can be derived quantities that explain its characteristics, such as size, shape, stream network and discharge. It involves a series of steps often on maps and imageries. Through the application of river morphometric analysis, it is possible to relate the influence of river systems on landforms or rock types and stage of development of the river (Raju and Babu, 2012). Morphometric parameters have been applied to catchment regions for various purposes, such as local flood hazard assessment by Loczy et al. (2009) in a large scale river alteration of a flood control project. It was used by Angillieri and Yanina (2008) to explain flash floods in several sub-basins of a river that posed risks to settlements downstream. A more extreme application of catchment basin morphometric by Singh et al. (2013) was to assess the groundwater endowment of a region. Another study by Raj and Azeez (2012) related basin geology, slope and rainfall pattern in the basin to determine the morphometric characteristics of the basin. The benefit of river basin morphometric analysis is the potential for prioritizing river basin development based on the outcome of the process (Vandana, 2013). In line with modern spatial analytical procedures, imageries and GIS has been applied to river basin morphometric as exemplified in the papers by Singh et al. (2013) and Magesh et al. (2013).

Recent applications of river basin morphometric in Nigeria include those of Eze and Efiong (2010) to the Calabar River system and Ajibade et al. (2010) to the Ogunpa and Ogbere river basins. The similarity in the two studies is that morphometric analysis was used to analyse flood hazards in densely populated urban regions as intended in this study. Previous analysis of Port Harcourt region's drainage as it pertains to flooding described the area as lacking significant differences in relief; therefore, rivers are characterized by sluggish flow velocity, ponded in many parts and tidal in others (Izeogu and Aisuebeogun, 1989; Umeudiji and Aisuebeogun, 1999). The consequence of absence of gradient as described by these authors is that of an area susceptible to flooding; however, the root of their observations was their reliance on topographic maps whose contour intervals were $15.24 \mathrm{~m}$ in elevation. Extant topographic maps of the area were used in this study to portray and extend contour lines to hitherto, flat surfaces at intervals of $3 \mathrm{~m}$. The result was a map with fairly crowded contour lines for the area described as Greater Port Harcourt, which comprises the old city and all the on-going developments and the proposed new city limits.

Precious N. Ede, Institute of Geosciences and Space Technology, Rivers State University of Science and Technology, Nkpolu-Oroworukwo, Port Harcourt, Nigeria. 
Surface Hydrological Setting of Port Harcourt Region

Port Harcourt metropolis is better defined by a broad area contained in the city master plan of 2008 referred to as Greater Port Harcourt City which spans $1900 \mathrm{~km}^{2}$ (Government of the Rivers State, 2008). This area is bordered on the east by the Otamiri/Imo River Basins and on the west by New Calabar River. The city proper is drained by the Bonny River and its main tributaries like, Elechi, Diobu, Woji and Okpoka. Most of these creeks originate from the catchment territory north of the city, roughly in the immediate north and south of the East-West Road between Choba and Rumuokrushi. Specific landmarks that depict the watershed to streams that feed the Bonny River are large depressions around Greater Port Harcourt Phase I, situated between Rumuosi, Aluu, and Eneka. Settlements like the University of Port Harcourt, the teaching hospital; Alakahia, Rumuosi/Ekini, Rumuoahuolu, Rumuokoro/Odumaya, Rukpakulusi, Eleozu, Rumunduru, Eliohani and Eneka are ponded to some extent as a result.

From the watershed, clear water divides and river systems can be discerned. This is the most western part of Port Harcourt; therefore, there is a water divide that enables flow into the new Calabar River system; on the other axis of the same river system, Elechi takes its source through Elioparanwo, Mbuoba and Rumuolumeni. The upper reaches of Diobu Creek (Ntawogba) begins at Orazi; roughly separated by Rumuola Road, Amadi creek originate from Rumuigbo/Omoi, through Bori camp, stadium Road via
Weja. Woji Creek begins from Rumuokoro and flows parallel to the East-West road up to Eliohani before draining towards Mini-Okoro. The headwaters at Atali and Rumuokurisi are the source for Elelenwo and Okpoka. All these streams drain into Bonny River and are entirely within Obio/Akpor, which is the local government area north of Port Harcourt City Local Government Area. Bonny River itself drains into the Bight of Bonny, off the Gulf of Guinea into the Atlantic Ocean through Bonny Town.

The network pattern of the rivers and creeks that drain Port Harcourt do not easily fit the conventional dendritic or trellised form. The surface forms are anastomosed channels of streams in their lower reaches; which prompted Areola (1983) to attribute the drainage as poor due to a combination of low relief, high water table and high rainfall. Obviously these are excellent conditions for surface ponding and flooding, especially at the peak of the rainy season. According to Umeduji and Aisuebeogun (1999) the presence of sandy formation as shallow as $12 \mathrm{~m}$ below the surface is evidence of ancient river courses, there are gradational lithological compositions consisting of profiles of white sand at medium coarse grains, often saturated to the surface. The numerous streams, rivers and creeks empty into the Bonny, at some point off Elechi Creek in the western side of the city; the Primrose Creek links Bonny River to the New Calabar River (see Figure 1). Flow direction is generally southern and south eastwards. For a sizable reach of the rivers and creeks there is semi-diurnal tidal regime of flows, with a maximum in September and October.

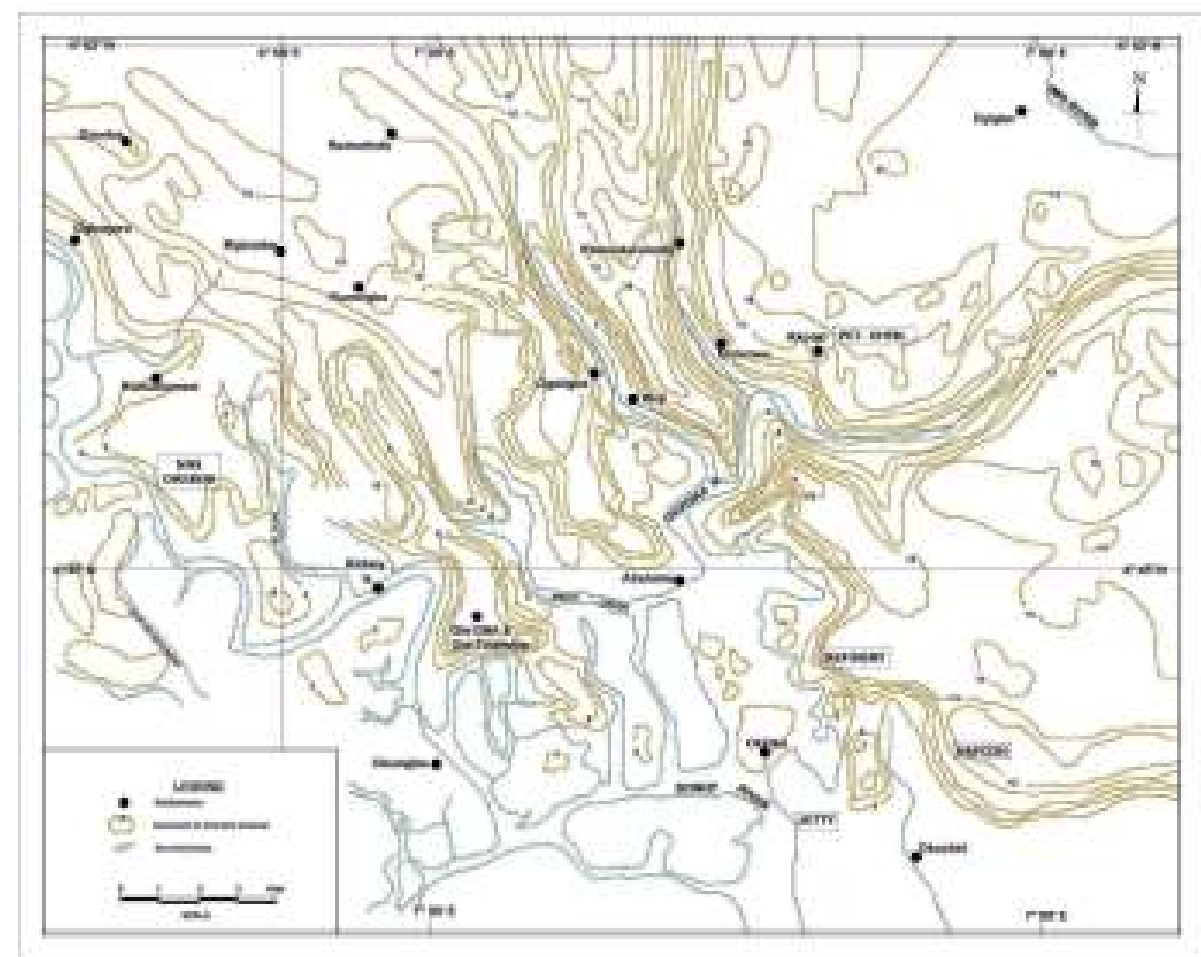

Figure 1: Relief and Drainage of Port Harcourt Region 
The high rainfall at this time of the year that guarantees maximum soil saturation also brings the ground water table very close to the surface. The coupling of a saturated soil and tidal surge daily inundates human habitations near the river banks, where precautions are hardly taken to raise structural foundations above the High Water Spring. In the Port Harcourt Master Plan 75, lands less than $3 \mathrm{~m}$ above mean sea-level were not supposed to be used for human habitat development. The poor within the city began squatting on such lands and a good proportion of the city's population live in what is locally termed "waterside" or "waterfront" settlements. They are the people most susceptible to seasonal tidal inundation. There are over 13 "waterside" settlements in the city of Port Harcourt and a quarter of the city's two million residents live in them (Government of the Rivers State, 2008).

\section{Human Influences on the topography}

Recent fluvial and geomorphic trends in the region has been analysed by Abam (2001) based on initial study by the Institute of Geosciences and Space Technology, IGST, in 1988, which indicated that there was a strong influx of flow and sediments to the coast. The regime was facilitated by the higher freshwater discharge in comparison to equivalent flood tide attributes. The portrayal by IGST (1988); Abam (2001) noted, does not accurately reflect what is known today, because the river network system that was responsible for redistribution flow and sediment from upstream sources were not recognised in their explanation. A subsequent analysis with this perspective mind of the characteristics of networked rivers explained the presence of large sections, which are starved of sediment and are as a result experiencing erosion. Abam's (2001) study however did not cover the Bonny River system, so it is not known if the river, which is in the same regional hydrological setting as the study rivers was affected by the human-induced trend.

Umeduji and Aisuebeogun (1999) identified slopes of $3^{0}-5^{0}$ in a NW-SE direction and many microrelief forms some of which are anthropogenic in Port Harcourt's landscape. The man-made morphological units are created out of ridge-like rail line and road structures. A good example of this is the Garrison, St. John's Campus of Ignatius Ajuru University and St Paul's Cathedral. There is a special flood characteristic of silver valley Estate, Oroworukwo, St. John's Bus Stop and $\mathrm{D} /$ line boundaries of this man-made ridge. Other examples are refuse domes and burrow pits scattered across the city. Around Location Road in Rumuola, there is a man-made pond that stretches over 10ha created apparently from laterite sand mining. Some major roads like the Eastern-bye-Pass, Reclamation Road, Sandfilled and New Road (Bolokiri) are examples of micro relief refinements with relevance to the city's morphology and recent flood drainage characteristics.

\section{Methodology}

Digital copies of thirty two sheets of topographic maps covering the entire study domain were assembled. The maps were of a scale 1:12000 and the features include contour intervals of $3 \mathrm{~m}$ complemented with spot heights. The relief and river system features of the area were delineated to establish drainage boundaries for morphometric analysis. Superimposing the topographic map on a general purpose map of the area further showed how urban development infrastructure may interface with basin morphometric. Field verifications were undertaken to authenticate certain parameters like tidal boundaries, river reaches and micro-relief features.

\section{RESULTS AND DISCUSSION}

The elevation ranges between $0 \mathrm{~m}$ in the south and $21 \mathrm{~m}$ above mean sea level in the north. The basin area $(A)$ is $239.6 \mathrm{~km}^{2}$ and the basin perimeter $(P)$ is $62.9 \mathrm{~km}^{2}$. Total channel length $(\mathrm{Ct})$ is $52 \mathrm{~km}$ and the basin length $(L) 22$. The basin relief is $0.0005 \mathrm{~m}$, reflecting the generally low gradient in the study area. The basin is a $3^{\text {rd }}$ order basin; there are 6 first order streams, 3 second order streams and 1 third order stream. Other parameters obtained include: bifurcation ratio $(\mathrm{Rb}=5)$, stream number $(\mathrm{Nu}=$ 10) and mean stream length $(\mathrm{Lu}=5.2)$. The drainage density (Dd) is 0.22 , while drainage intensity (Di) is 5.4 and stream frequency $(F)$ is $0.04 \mathrm{~km}^{2}$. The Upper Bonny basin form is illustrated in Figure 2. 


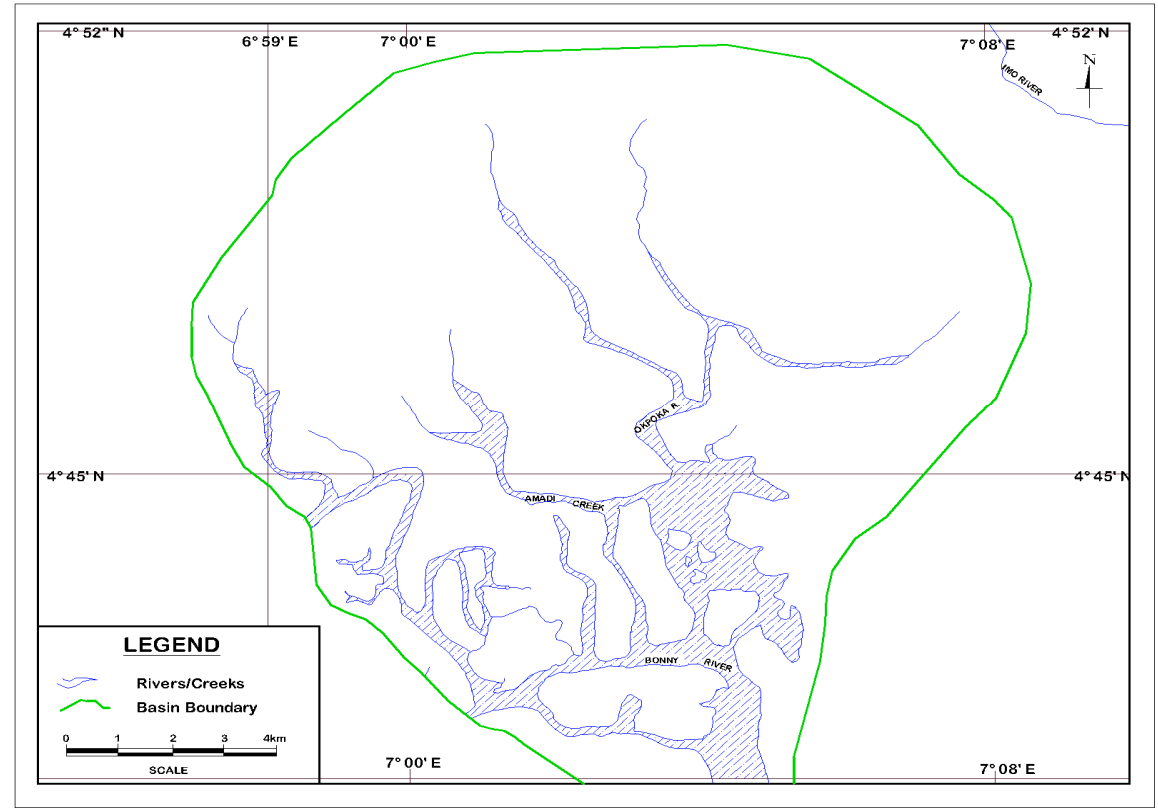

Figure 2: Port Hacourt's Drainage Basin

The area's topography is rolling and fairly flat. It is characterised by marshlands on depressions and river beds; both old and new to the north. Elevations are much lower in the southern side; the numerous streams and creeks are associated with large expanses of mudflats, floodway and floodplains. Table 1 details the elevation of some locations in the study area; Elingbu and Eneka $(20-21 \mathrm{~m})$ located in the northeast are the highest points. The lowest points are part of the old city bordering the Dockyard and Borokiri $(0-10 \mathrm{~m})$. All the river sections below $5 \mathrm{~m}$ elevation are tidal. The general direction of slope is NS as with many of the streams.
Almost all the neighbourhoods are located next to water courses where the elevations invariably drop to $10 \mathrm{~m}$ or below.

The headwaters of the streams are a series of shallow depressions oriented southeast, with an average depth of $5 \mathrm{~m}$ that were formed in the northern boundaries of the city. Their elongated nature is suggestive of abandoned river courses and lakes during previous pluvial periods. These depressions occur at elevations of between 15 and $21 \mathrm{~m}$ and are a source of flooding in the otherwise least floodable area northern axis

city.

Table 1: Neighbourhoods' elevation in the study area

\begin{tabular}{|l|l|l|l|}
\hline Neighbourhood & $\begin{array}{l}\text { Maximum } \\
\text { Elevation }(\mathrm{m})\end{array}$ & $\begin{array}{l}\text { Stream/creek } \\
\text { Name }\end{array}$ & $\begin{array}{l}\text { Nearby Stream } \\
\text { elevation }(\mathrm{m})\end{array}$ \\
\hline Eagle Island & 5 & Elechi & 0 \\
\hline Borikiri & 6 & Okubiakri & 0 \\
\hline Abuloma & 9 & Okpoka & 0 \\
\hline Rumuolumeni & 9 & Elechi & 0 \\
\hline Old Township & 12 & Dockyard & 0 \\
\hline Old GRA & 12 & Diobu & 0 \\
\hline Amadi Ama & 12 & Amadi & 0 \\
\hline Orogbum & 12 & Amadi & 0 \\
\hline D/line & 10 & Ntawogba & 3 \\
\hline Elekahia & 15 & Weja & 3 \\
\hline GRA Phase II & 12 & Ntawogba & 4 \\
\hline PH Refinery & 15 & Okpoka & 0 \\
\hline Akpajo & 15 & Okpoka & 0 \\
\hline Rumuigbo & 12 & Amadi & 10 \\
\hline Rumuokoro & 15 & Woji & 12 \\
\hline Eneka & 18 & Elelenwo & 9 \\
\hline Rumuokurusi & 18 & Elelenwo & 6 \\
\hline Elimgbu & 21 & Mini Ocha & 9 \\
\hline
\end{tabular}


The depressions form large ponds of water that measure between $5-10 \mathrm{~km}^{2}$; examples are within the new housing estate in Eneka $\left(6.3 \mathrm{~km}^{2}\right)$ and adjacent community secondary school, Nkpolu-Rumuigbo $\left(8.4 \mathrm{~km}^{2}\right)$ and between Mgbuoba and Rumuokuta $\left(5.4 \mathrm{~km}^{2}\right)$. Surface ponding in these depressions almost dries up during the dry season, depending on the time of the year and amount of rainfall experienced. When fully recharged; they remain a reservoir source for flood water, not just in the downstream direction, but also for their immediate neighbourhoods.

In low rainfall years, land speculators unwittingly move in to develop properties within or near the boundaries of these depressions. These incursions are made without adequate mitigation for flood, as a consequence there are many high-end housing estates, such as the ones in Eneka and Mgbuoba regularly inundated for as much $5 \mathrm{~m}$ deep, at the peak of the rainy season (July-September). Until 2008 when the greater city master plan was commissioned, city planning laws barely applied to the northern fringe of the metropolis where these depressions are found. Due to degraded communal cohesion and absence of serious policing, land speculators demarcate plots with high concrete fences. From a surface hydrological perspective, concrete fences are dams that impede surface water flow, hence, flooding in these areas are made even more severe. In model experiments and numerical simulations using the Kanako2D debris flow simulator to determine the influence of houses on debris flow flooding and deposition, Nakatani et al. (2013) established that buildings interact with debris flow to cause flooding. Our observation in this study is that concrete fences exert the same effect.

Astronomic High Water Spring that causes tidal swells occurs in September-October, coinciding with the period of maximum rainfall and saturation soil moisture content. Summaries based on Navy Hydrographic Office, Lagos, as reported by the Government of the Rivers State (2008) estimates the Mean High Water Spring as $2.530 \mathrm{~m}$. Since the mean sea level is $1.463 \mathrm{~m}$ $\mathrm{Msl}$, the total elevation of the High Astronomic Tide in Port Harcourt is $3.993 \mathrm{~m}$ Msl. This has three implications:

a) It is inexpedient to allow human settlement activities on lands below $5 \mathrm{~m}$ unless elaborate protection measures such as dykes, levees and embankment walls are first provided.

b) All flood and sewer discharge facilities emptying into the Bonny River system where elevations are less than $5 \mathrm{~m}$ above mean sea level should not be mounted below the Astronomic High Water Spring.

c) Laterally and irrespective of elevation, the new city master plan recommends a setback limit of $50 \mathrm{~m}$ from waterways. This buffer zone is recommended for recreational uses, where appropriate.

The river banks in the southern half of the metropolis are generally below $5 \mathrm{~m}$ in elevation; due to tidal flood regime to which south of the city is prone, very low lying places can be flooded. Tidal effects in the reaches of streams across the city could be up to $10 \mathrm{~km}$ inland (Government of the Rivers State, 2008). The three triggers of flood, namely: water saturated soil leading to groundwater coming close to the surface, excessive runoffs from storm water and tides above the Astronomic High Water Spring synergise to raise flood risks. The extensive areas of the tidally inundated mudflats south of Port Harcourt, locally termed 'water fronts' or 'watersides' have been variously reclaimed by the government, community and individuals. Over 13 of such neighbourhoods are so designated within the city and they are all situated below $5 \mathrm{~m}$ Msl. Two examples of such neighbourhoods are Borokiri Sand-filled and Bundu Waterside. In the peak flood period, these neighbourhoods experience daily flooding that rises and ebbs with tide. The month of September with a mean monthly rainfall of $368 \mathrm{~mm}$, and extremes as high as 718 $\mathrm{mm}$ and at least 25 rainy days (Akintola, 1986) amplifies the flooding of the waterfront neighbourhoods.

\section{CONCLUSIONS}

Morphometric parameters have been applied in this study to evaluate Port Harcourt's catchment basin for the purposes of local flood hazard assessment. Findings show that the area covered by the greater Port Harcourt region is susceptible to flooding because of natural and human factors. The depressions in the north that are perennially ponded should be properly drained unless city planners intend to retain them as marshland surrounded by urban development. Draining is relatively cheap and beneficial because the depressions on which the ponding occur are all situated on higher grounds; therefore, nick points of canal that release water can resolve the ponding. Moreover, the need to enhance biodiversity as an argument if the ponded area are to be retained, has to be weighed against loss of valuable land for development, greater potential for flooding and a swamp that nurtures disease vectors like mosquitoes. This option will take the concept of urban green verge to the extreme; because such forest will be thick and swampy. The use of impermeable concrete for plot fencing should also be restricted in this part of the city to allow for overland free drainage of storm waters. Very low gradient is partly responsible for flooding in the lower reaches of streams. This can be curtailed if existing regulations which forbid housing development on lands below $3 \mathrm{~m}$ above mean sea level are rigorously enforced. Construction of storm water drainage in the area should as well take into account the low terrain, such that drains are not delivered at elevations below the Astronomic High Water Spring to avoid backflows.

\section{REFERENCES}

Abam, T. K. S., 2001. Regional hydrology research perspectives in the Niger Delta. Hydrological Sciences Journal, 46, (1):

Akintola, F. O., 1986. Rainfall Distribution in Nigeria 1892-1983. Impact Publishers, Ibadan, 380pp.

Ajibade, L. T., Ifabiyi, I. P., Iroye, K. A and Ogunteru, S., 2010. Morphometric analysis of Ogunpa and Ogbere drainage basins, Ibadan, Nigeria. Ethiopian 
Journal of Environmental Studies and Management 3, (1): 13-19.

Angillieri, E and Yanina, M., 2008. Morphometric analysis of Colangüil river basin and flash flood hazard, San Juan, Argentina. Environmental Geology, 55, (1): 107-111.

Areola, O. O., 1983. Soil and vegetation resources. In Oguntoyinbo, J. S., Areola, O. O. and Filani, M. (eds.): A Geography of Nigeria Development. Heinemann, Ibadan, 105-126.

Eze, E. B and Efiong, J., 2010. Morphometric parameters of the Calabar River basin: implication for hydrologic processes. Journal of Geography and Geology 2, (1): 18 -26.

Government of the Rivers State., 1975. Port Harcourt Master Plan 75. Specialist Consult, Stockholm.

Government of the Rivers State., 2008. The Greater Port Harcourt City Development Plan. Arcuss Gibb, Port Harcourt, 121.

IGST., 1988. Master Plan Design of Flood and Erosion Control Measures in the Niger Delta. Technical Progress Report No 1, Institute of Geosciences and Space Technology, Rivers State university of Science and Technology, NkpoluOroworukwo, Port Harcourt.

Izeogu, C. V and Aisuebeogun, A. O., 1989. Relief and drainage. In E. J. Alagoa and T. N. Tamuno, (eds.) Land and People of Nigeria: Rivers State, Port Harcourt: Riverside Communications, 2430.

Loczy, D., Kis, E and Schweitzer., 2009. Local flood hazards assessed from channel morphometry along the Tisza River in Hungary. Geomorph. 113, (3-4): 200-209.

Magesh, N. S., Jitheshlal, K. V., Chandrasekar, N and Jini, K. V., 2013. Geographical information systembased morphometric analysis of Bharathapuzha river basin, Kerala, India. Appl Water Sci. 3:467-477.

Nakatani, K., Okuyama, Y., Hasegawa, Y., Satofuka, Y and Mizuyama, T., 2013. Influence of housing and urban development on debris flow flooding and deposition. J. Mt. Sci. 10, (2): 273-280.

Raj, P. P. N and Azeez, P. A., 2012. Morphometric analysis of a tropical medium river System: a case from Bharathapuzha River southern India Open Journal of Modern Hydrology, (2): 91-98.

Raju, G. S and Babu, K. R., 2012. Morphometric analysis of Kunderu River basin, Kurnool district, A.P, India for watershed management. J Environ Sci Eng. 54, (1): 85-9.
Singh, P., Thakur, J. K and Singh, U. C., 2013. Morphometric analysis of Morar River basin, Madhya Pradesh, India, using remote sensing and GIS techniques. Environ Earth Sci., (68): 1967-1977.

Umeuduji, J. E and Aisuebeogun, A., 1999. Relief and drainage. In C. U. Oyegun and A. Adeyemo, (eds.): Port Harcourt Region, Port Harcourt: Department of Geography and Environmental Management, Publication Series; No.1.

Vandana, M., 2013. Morphometric analysis and watershed priotisation: a case study of Kabani river basin, Wayanad district, Kerala, India. Indian Journal of Geo-Marine Sciences, 42, (2): 211-222. 